\title{
Amino acid metabolism in the piglet
}

\section{Influence of lysine level in the diet on energy metabolism and in vivo oxidation*}

\author{
By E. R. CHAVEZ AND H. S. BAYLEY \\ Department of Nutrition, University of Guelph, Guelph, Ontario $N_{\mathrm{I}} G_{2} W_{\mathrm{I}}$, Canada \\ (Received I6 October 1975-Accepted 2 Fune 1976)
}

\begin{abstract}
I. Supplementing a lysine-deficient diet $(5 \mathrm{~g}$ lysine $/ \mathrm{kg}$ ) with five increments of lysine, each of $2 \mathrm{~g} / \mathrm{kg}$, resulted in increases in growth rate of Yorkshire piglets, aged between 3 and 7 weeks, up to the highest level of lysine $(15 \mathrm{~g} / \mathrm{kg}$ ).

2. The free lysine concentration of plasma tended to increase as the dietary lysine level increased from 13 to $I 5 \mathrm{~g} / \mathrm{kg}$, and plasma threonine concentration decreased significantly as the lysine content of the diet was increased from I to $15 \mathrm{~g} / \mathrm{kg}$ indicating that threonine was the second limiting amino acid in the diet.

3. Oxygen consumption and carbon dioxide production of the piglets were not influenced by supplementing the diets with lysine. The heat production was $0.313 \mathrm{~kJ} / \mathrm{min}$ per $\mathrm{kg}$ body-weight in the $6 \mathrm{~h}$ experimental period.

4. Supplementation of the diet with lysine had no consistent effect on the recovery of ${ }^{14} \mathrm{C}$ as ${ }^{14} \mathrm{CO}_{2}$ from a single dose of $\mathrm{L}-\left[\mathrm{U}-{ }^{14} \mathrm{C}\right]$ lysine.

5. Adjustment of the determined recoveries of the tracer dose of lysine for the differences in the plasma concentrations of free lysine for the pigs receiving the graded levels of dietary lysine simplified the relationship between recovery and dietary lysine level: it was linear for the first four increments in dietary lysine and then increased sharply for the fifth increment. This indicated that a marked change in the rate of lysine catabolism occurred as the level of dietary lysine was increased from 13 to $5 \mathrm{~g} / \mathrm{kg}$.

6. The results of this experiment indicate that the piglets' requirement for lysine is between 13 and $15 \mathrm{~g}$ lysine $/ \mathrm{kg}$ in a diet which contained $18 \mathrm{I} \mathrm{g}$ crude protein (nitrogen $\times 6.25$ ) $/ \mathrm{kg}$.
\end{abstract}

The influence of amino acid level in the diet on growth and carcass development of growing-finishing pigs is well defined and the 'requirements' for the essential amino acids recommended by the Agricultural Research Council (1967) and the (US) National Research Council (1973) are widely used as a basis for the formulation of practical diets. In contrast, the influence of amino acid levels in the diets of young pigs (less than 1o kg live weight) are less well defined and their 'requirements' are based on extrapolation from results obtained with older pigs. Thus it would be useful to study the influence of dietary levels of amino acids on the growth and development of young pigs ( 3 weeks of age and $5 \mathrm{~kg}$ live weight).

There have been difficulties in defining the amino acid requirement of the young pig using techniques which have been used with older pigs. Gallo, Pond \& Logomarsino (1968), who used growth as a response measurement found that young pigs (7-14 kg live weight) did not respond to amino acid supplementation of a low-protein diet as well as older pigs ( $50-100 \mathrm{~kg}$ ) had done in an earlier experiment (Gallo \& Pond, 1968). Knipfel, Keith, Christensen \& Owen (1972) were unable to determine the methionine requirement of the weanling pig $(7 \mathrm{~kg})$ by measuring the influence of dietary methionine level on the methionine concentration in serum, even though the technique had been used satisfactorily with pigs weighing $18 \mathrm{~kg}$ (Keith, Christensen 8

* Paper no. 2: Br. F. Nutr. (1976), 36, 189. 
Owen, 1972). Oestemer, Hanson \& Meade (I973) attempted to determine the isoleucine requirement of the young pig $(6 \mathrm{~kg})$ but found different estimates with each of the response measurements they used; their estimates ranged from $3.8 \mathrm{~g} / \mathrm{kg}$ diet when they used free isoleucine concentrations in plasma, to $5.2 \mathrm{~g} / \mathrm{kg}$ diet when they used growth rate. Both values are less than the 'requirements' of 9 and $6.9 \mathrm{~g} / \mathrm{kg}$ diet recommended by the Agricultural Research Council ( 1967 ) and the (US) National Research Council (1973) respectively. However, Zimmerman (1975) estimated the tryptophan requirement of the young pig $(5-10 \mathrm{~kg}$ ) to be $1.5 \mathrm{~g} / \mathrm{kg}$ diet, and this estimate was consistent whether he used growth rate, food conversion, free tryptophan concentration in plasma or plasma urea concentration as response criteria.

As the intake of an amino acid increases from levels lower than the amount which is needed for the maximum rate of protein synthesis to levels greater than this amount, there will be a shift in the metabolic fate of the incremental amount of the amino acid from anabolism to catabolism. There are several indicators of this change: growth rate reaches a plateau, there is an increase in the concentration of the amino acid in the plasma (Zimmerman \& Scott, 1965 ), there is an increase in the rate at which the amino acid is oxidized (Brookes, Owens \& Garrigus, 1972), and there is a decrease in the conversion of the nitrogen from the other dietary amino acids to urea (Brown \& Cline, 1974).

Excessive levels of dietary protein reduced energy retention in the young pig (Gray \& McCracken, 1974), however, no effects of amino acid (methionine) balance in the diet on energy retention were found by Walker (1974) who worked with lambs, or by Trela (1973) who used chickens.

In the present study, growth, energy metabolism and amino acid metabolism of young pigs receiving diets containing graded levels of lysine were studied, in an effort to define the dietary levels which would support maximum growth and which would minimize lysine catabolism.

\section{EXPERIMENTAL}

Twenty-four Yorkshire piglets were weaned at $18 \mathrm{~d}$ of age and transferred to individual cages in the laboratory. Details of the lysine-deficient basal diet are given in Table $\mathrm{r}$, it was supplemented with five increments of $2 \mathrm{~g} \mathrm{~L}-\mathrm{lysine} \mathrm{HCl} / \mathrm{kg}$. Samples of the diets were analysed; the proximate composition was determined using the Association of Official Agricultural Chemists' (1970) procedures and the amino acid composition of an hydrolysate of the diet was determined as described by Chavez \& Bayley (1976).

The piglets received the experimental diets ad lib. and water was available at all times. The piglets were weighed each week for the 4-week experimental period and food consumption was recorded daily. A catheter was passed through a jugular vein into the vena cava to permit blood sampling and infusion of the tracer dose of ${ }^{14} \mathrm{C}$ labelled amino acid, as described by Newport, Chavez, Horney \& Bayley (1976). Blood samples, gas exchange and amino acid oxidation studies were done when the piglets were between 6 and 7 weeks of age. 
Table I. Composition $(\mathrm{g} / \mathrm{kg})$ of the experimental basal diet

\begin{tabular}{|c|c|c|c|}
\hline Ingredients & $\begin{array}{l}\text { Lysine- } \\
\text { deficient }\end{array}$ & $\begin{array}{l}\text { Chemical } \\
\text { composition }\end{array}$ & $\begin{array}{l}\text { Lysine- } \\
\text { deficient }\end{array}$ \\
\hline $\begin{array}{l}\text { Maize starch* } \\
\text { Isolated sovbean proteint }\end{array}$ & $409 \cdot 5$ & $\begin{array}{l}\text { Ash } \\
\text { Gross eneroy }(\mathrm{MI} / \mathrm{k} \alpha)\end{array}$ & $5 \mathrm{r} \cdot 3$ \\
\hline & - & Gross energy $(\mathrm{M} 1 \mathrm{~J} / \mathrm{kg})$ & $16 \cdot 9$ \\
\hline $\begin{array}{l}\text { Sunflower meal } \\
\text { Maize-gluten meal }\end{array}$ & $235^{\circ} 0$ & Calcium & $7 \cdot 0$ \\
\hline Maize-gluten meal & $165^{\circ} 0$ & Phosphorus & $7 \cdot 2$ \\
\hline Cellulose + & 118.5 & Essential amino acids & \\
\hline Maize oil & $20 \cdot 0$ & Methionine & $5 \cdot 2$ \\
\hline Limestone & & Cystine & I.O \\
\hline Dicalcium phosphate & $24 \cdot 0$ & Lysine & \\
\hline Salt $(\mathrm{NaCl})$ & $3 \cdot 0$ & Arginine & $8 \cdot 1$ \\
\hline Vitamin mixई & $5^{\circ} \circ$ & Histidine & 3.4 \\
\hline Mineral mix \| & $\begin{aligned} 10 \cdot 0 \\
2 \cdot 0\end{aligned}$ & Isoleucine & $6 \cdot 9$ \\
\hline CL-methionine & & Leucine & 17.9 \\
\hline $\begin{array}{l}\text { Chemical composition } \\
\text { Moisture } \\
\text { Crude protein (nitrogen } \times 6.25 \text { ) } \\
\text { Fat } \\
\text { Crude fibre }\end{array}$ & $\begin{array}{r}89 \cdot 3 \\
191 \cdot 0 \\
28 \cdot 0 \\
112 \cdot 8\end{array}$ & $\begin{array}{l}\text { Phenylalanine } \\
\text { Tyrosine } \\
\text { Threonine } \\
\text { Valine }\end{array}$ & $\begin{array}{l}9 \cdot 0 \\
5 \cdot 8 \\
5 \cdot 1 \\
8 \cdot 2\end{array}$ \\
\hline \multicolumn{4}{|c|}{ 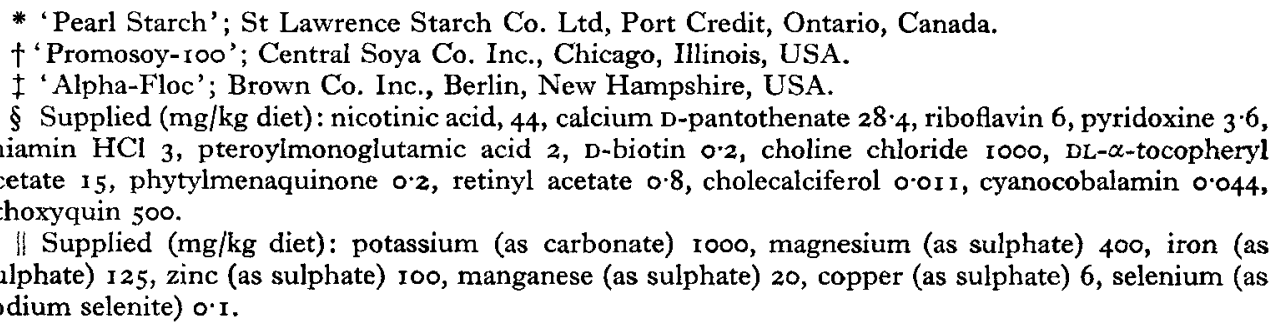 } \\
\hline
\end{tabular}

\section{Measurement of oxygen consumption, carbon dioxide and ${ }^{14} \mathrm{CO}_{2}$ production}

The pig was confined in an environmental chamber $(980 \times 600 \times 900 \mathrm{~mm})$ (Accumatic test chamber; Hotpack Ltd, Waterloo, Ontario, Canada), from which air was withdrawn with variable-speed pumps (Fig. I). The total volume of air was measured using dry test meters (DTM 200; Canadian Meter Co. Ltd, Milton, Ontario, Canada). The temperature in the chambers was maintained at $26^{\circ}$ and the relative humidity $40 \%$. A ventilation rate of approximately $151 / \mathrm{min}$ was sufficient to ensure that the concentration of $\mathrm{CO}_{2}$ remained below $\mathrm{I} \%$ in the air pumped from the chamber. A sample of air from either of the two chambers could be passed through $\mathrm{O}_{2}$ and $\mathrm{CO}_{2}$ analysers (models $\mathrm{G}_{2}$ and $\mathrm{IR}_{21}{ }_{5} \mathrm{~A}$ respectively; Beckman Instruments Inc., Fullerton, California, USA), and then returned to the main gas stream. The outputs from the gas analysers were digitized and recorded on a teleprinter (Compact I Data Logger; Solartron Ltd, Farnworth, Hants, UK).

Six analyses of the gas which was being pumped from each of the two chambers were made during each hour of the $6 \mathrm{~h}$ experimental period. All the air from the chambers was passed through a series of traps which contained organic solvents to absorb the $\mathrm{CO}_{2}$. The solvents in the $\mathrm{CO}_{2}$ absorbers were changed at $30,60,90, \mathrm{I} 20$, $150,210,270$ and $360 \mathrm{~min}$ after the pumps were restarted $30 \mathrm{~min}$ following infusion of the ${ }^{14} \mathrm{C}$-labelled lysine. The gas analysers were calibrated using gas mixtures 


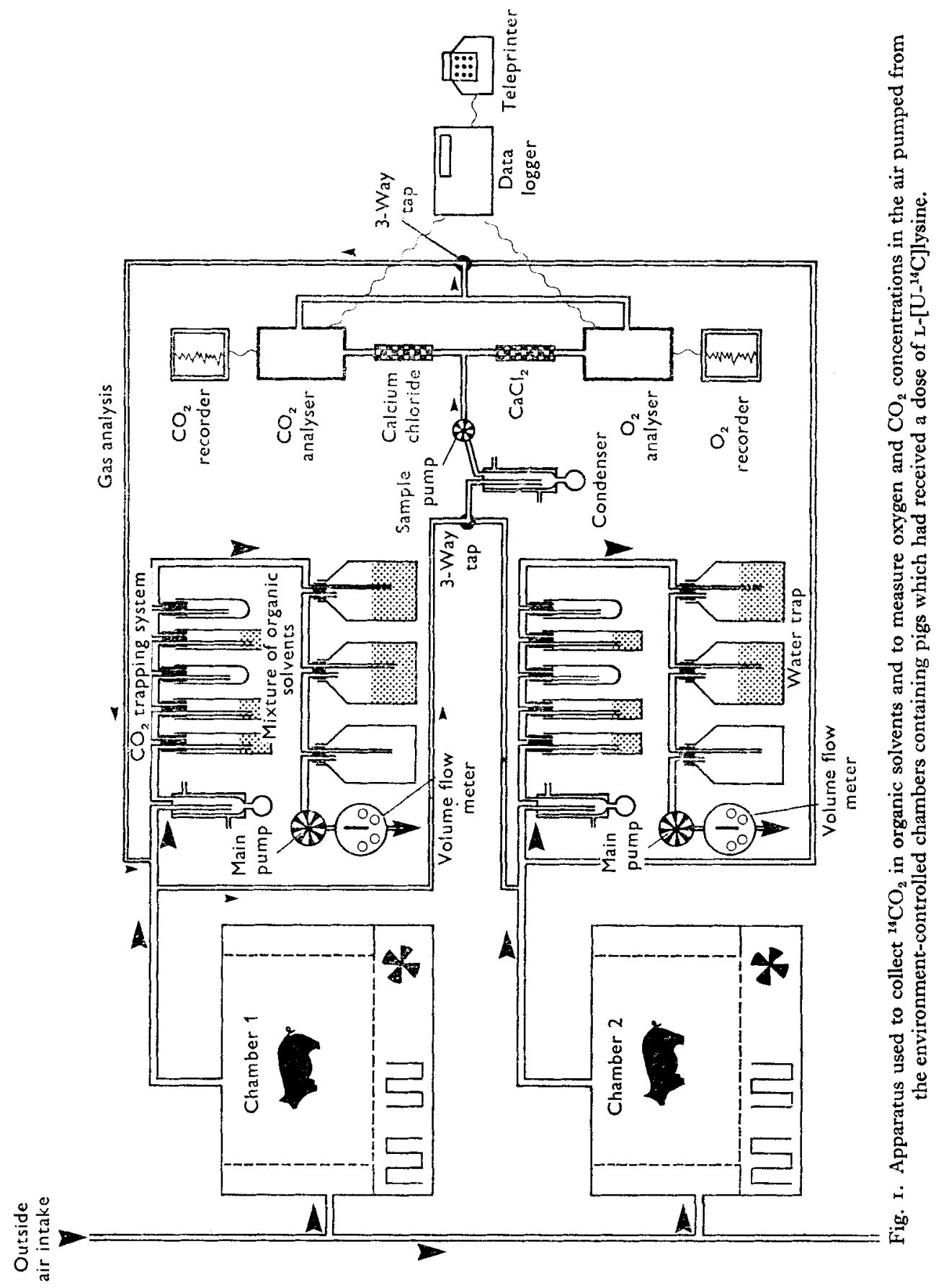


prepared from cylinders of high purity $\mathrm{CO}_{2}, \mathrm{~N}_{2}$ and $\mathrm{O}_{2}$ (Matheson Ltd, Whitby, Ontario, Canada) with precision gas-mixing pumps (models SA-18 and -27; Wosthoff AG, Bochum, W. Germany). Heat production was calculated from $\mathrm{O}_{2}$ consumption and $\mathrm{CO}_{2}$ production using the relationship described by Kleiber (I96I). The amount of radioactivity in the $\mathrm{CO}_{2}$ absorbed by the solvents was determined by liquid-scintillation counting as described by Newport et al. (1976).

The samples were counted with an efficiency of $67 \%$. The procedure for collecting ${ }^{14} \mathrm{CO}_{2}$ was verified by infusing $\mathrm{I} \mu \mathrm{Ci} \mathrm{NaH}{ }^{14} \mathrm{CO}_{3}$ into the pigs: $90 \%$ of the activity was recovered in the organic solvents in the $6 \mathrm{~h}$ collection period.

\section{Infusion of labelled amino acids and blood sampling}

L-[U_- $\left.{ }^{14} \mathrm{C}\right]$ lysine $\left(3{ }^{18} \mathrm{mCi} / \mathrm{mmol}\right)$ was purchased from Amersham-Searle Ltd, Don Mills, Ontario, and was diluted in saline $(9 \mathrm{~g} \mathrm{NaCl} / 1)$ so that the $\mathrm{I} \mathrm{ml}$ dose contained $2 \mu \mathrm{Ci}\left[{ }^{14} \mathrm{C}\right]$ lysine. The piglets were weighed and at 19.00 hours were placed in the chamber where they had access to water but no food. The chambers were ventilated but there were no solvents in the $\mathrm{CO}_{2}$ absorption vessels. At 09.00 hours the next day the chamber was opened, a blood sample taken from the catheter, and the tracer dose of ${ }^{14} \mathrm{C}$-labelled lysine infused. The catheter was flushed with heparinized saline and the appropriate diet was placed in a feeder inside the chamber. The chamber was sealed and solvents were placed in the $\mathrm{CO}_{2}$ absorption vessels.

The blood samples were prepared for amino acid analyses as described by Chavez \& Bayley (1976).

The results were subjected to analyses of variance and the statistical significance of the results assessed by calculating the 'honestly significant difference' of Tukey at $P<0.05$, as described by Steel \& Torrie (1960).

\section{RESULTS}

The lysine-deficient diet contained $4.7 \mathrm{~g}$ lysine/kg (Table $\mathrm{x}$ ) which is only half the 'requirement' recommended by the (US) National Research Council (1973), and on the basis of these requirements there were marginal deficiencies of the sulphur amino acids and of threonine; the isoleucine content was equal to the requirement.

Cumulative average daily food consumption and weight gain (Table 2) indicated that the pigs grew faster as the level of lysine in the diet was increased. There was no indication that a plateau had been reached in the growth response of these pigs by increasing the level of lysine to $15 \mathrm{~g} / \mathrm{kg}$ diet.

Increasing the level of lysine in the diet had no significant effect on the lysine concentration in the plasma (Table 3), however, there was a significant increase in the concentrations of leucine and valine as the lysine level in the diet was increased from I 3 to $15 \mathrm{~g} / \mathrm{kg}$. In contrast there was a significant decrease in the concentration of threonine in the plasma as the level of lysine in the diet increased, with a marked decrease as the dietary level was increased from I I to $13 \mathrm{~g} / \mathrm{kg}$. These changes in the plasma threonine concentrations are particularly noteworthy, because calculation 
Table 2. Cumulative daily food consumption ( $g$ ) and body-weight gain $(g / d)$, each week for 4 weeks, for growing piglets given graded levels of lysine in a semi-purified diet* containing $200 \mathrm{~g}$ crude protein (nitrogen $\times 6 \cdot 25$ ) $/ \mathrm{kg}$

(Mean values for four piglets/treatment)

\begin{tabular}{|c|c|c|c|c|c|c|c|c|}
\hline $\begin{array}{l}\text { Dietary } \\
\text { Age } \\
\text { (weeks) }\end{array}$ & lysine $(\mathrm{g} / \mathrm{kg})$ & $\begin{array}{ll}. \cdot 5 \\
6\end{array}$ & 7 & 9 & I I & 13 & I5 & $\mathrm{SE}(\mathrm{I} 8 \mathrm{df})$ \\
\hline $3-4$ & $\begin{array}{l}\text { Food intake } \\
\text { Wt gain }\end{array}$ & $\begin{array}{l}\mathbf{I} 6 \mathbf{2} \\
8 \mathrm{I}^{a b}\end{array}$ & $\begin{array}{l}\text { I } 39 \\
54^{b}\end{array}$ & $\begin{array}{l}\text { I08 } \\
47^{b}\end{array}$ & $\begin{array}{l}148 \\
92^{a b}\end{array}$ & $\begin{array}{l}171 \\
101^{a b}\end{array}$ & $\begin{array}{l}199 \\
176^{a}\end{array}$ & $\begin{array}{l}23 \\
27\end{array}$ \\
\hline $3-5$ & $\begin{array}{l}\text { Food intake } \\
\text { Wt gain }\end{array}$ & $\begin{array}{l}188 \\
65^{6}\end{array}$ & $\begin{array}{r}183 \\
74^{b}\end{array}$ & $\begin{array}{l}54 \\
71^{b}\end{array}$ & $\begin{array}{l}204 \\
112^{a b}\end{array}$ & $\begin{array}{l}201 \\
76^{a b}\end{array}$ & $\begin{array}{l}234 \\
151^{a}\end{array}$ & $\begin{array}{l}24 \\
17\end{array}$ \\
\hline $3-6$ & $\begin{array}{l}\text { Food intake } \\
\text { Wt gain }\end{array}$ & $\begin{array}{l}\text { I } 95^{a b} \\
70^{a}\end{array}$ & $\begin{array}{c}191^{a b} \\
91^{a}\end{array}$ & $\begin{array}{r}180^{b} \\
88^{a}\end{array}$ & $\begin{array}{l}225^{a b} \\
122^{a}\end{array}$ & $\begin{array}{c}237^{a b} \\
98^{a}\end{array}$ & $\begin{array}{l}264^{a} \\
146^{a}\end{array}$ & $\begin{array}{l}18 \\
17\end{array}$ \\
\hline $3-7$ & $\begin{array}{l}\text { Food intake } \\
\text { Wt gain }\end{array}$ & $\begin{array}{l}195 \\
63^{b}\end{array}$ & $\begin{array}{l}\mathrm{I} 92 \\
100^{a b}\end{array}$ & $\begin{array}{l}22 \mathrm{I} \\
94^{a b}\end{array}$ & $\begin{array}{l}242 \\
123^{a b}\end{array}$ & $\begin{array}{l}275 \\
134^{a b}\end{array}$ & $\begin{array}{l}278 \\
152^{a}\end{array}$ & $\begin{array}{l}21 \\
16\end{array}$ \\
\hline
\end{tabular}

hsd, 'Honestly significant difference' of Tukey at $P>0.05$, as described by Steel \& Torrie (1960).

Values with the same superscript were not significantly different: $P \leqslant 0.05$.

* For details of composition, see Table I.

Table 3. Essential amino acid concentrations ( $\mu \mathrm{mol} / \mathrm{l}$ ) in the plasma of growing piglets given graded levels of lysine in a semi-purified diet* containing $200 \mathrm{~g}$ crude protein (nitrogen $\times 6 \cdot 25) / \mathrm{kg}$

(Mean values for four piglets/treatment)

\begin{tabular}{|c|c|c|c|c|c|c|c|c|}
\hline Dietary lysine (g/kg) & $\ldots 5$ & 7 & 9 & I I & 13 & I5 & & \\
\hline Amino acid & & & & & & & SE (I $8 \mathrm{df})$ & hsd \\
\hline Lysine & 99 & 88 & 72 & $8_{3}$ & 88 & 125 & 18 & 79 \\
\hline Arginine & 35 & 37 & 43 & 48 & 67 & 52 & I I & 49 \\
\hline Histidine & 35 & 35 & 35 & 39 & 38 & 31 & 5 & 21 \\
\hline Isoleucine & $37^{b}$ & $40^{b}$ & $47^{a b}$ & $48^{a b}$ & $45^{a b b}$ & $69^{\alpha}$ & 6 & 27 \\
\hline Leucine & 59 & 55 & 64 & 66 & 69 & 99 & 10 & 45 \\
\hline Methionine & 27 & 34 & 33 & 31 & 28 & 32 & 3 & I 4 \\
\hline Phenylalanine & 51 & 54 & 47 & 50 & 50 & 57 & 5 & 22 \\
\hline Threonine & $179^{a}$ & $\mathrm{I} 53^{a b}$ & $129^{a b c}$ & $125^{a b c}$ & $88^{b c}$ & $67^{c}$ & r 8 & 82 \\
\hline Valine & 89 & 85 & 99 & 103 & 94 & 134 & 13 & 60 \\
\hline Total & $6 \mathrm{II}$ & $58 I$ & 569 & 593 & $5^{67}$ & 666 & & \\
\hline
\end{tabular}

hsd, 'Honestly significant difference' of Tukey at $P>0.05$, as described by Steel $\&$ Torrie (1960).

Values with the same superscript were not significantly different: $P \leqslant 0.05$.

* For details of composition, see Table $\mathrm{I}$.

indicated that it was the second limiting amino acid in the lysine-deficient basal diet. These values suggested that the supply of threonine in the diet began to be limiting as the level of lysine was increased from I I to $\mathrm{r} 3 \mathrm{~g} / \mathrm{kg}$ diet.

The studies of energy metabolism in the pigs were made after they had received the experimental diets for 2 weeks, and those which had received the lower levels of dietary lysine tended to weigh less than those which had received the higher levels of dietary lysine (Table 4 ). They all consumed food during the experimental period but the low values obtained for respiratory quotients $(\mathrm{RQ})$ indicated that only a small part was digested and metabolized during this period. However, the RQ for the pigs which had received the diet containing I I $\mathrm{g}$ lysine/kg was significantly higher than for those which had received the diet containing $5 \mathrm{~g}$ lysine $/ \mathrm{kg}$. Heat production was unaffected 
Table 4. Oxygen consumption, carbon dioxide production and heat production, during a $6 \mathrm{~h}$ period, of growing piglets (6-7 weeks of age) given graded levels of lysine in a semipurified diet* containing $200 \mathrm{~g}$ crude protein (nitrogen $\times 6 \cdot 25) / \mathrm{kg}$

(Mean values for four piglets/treatment)

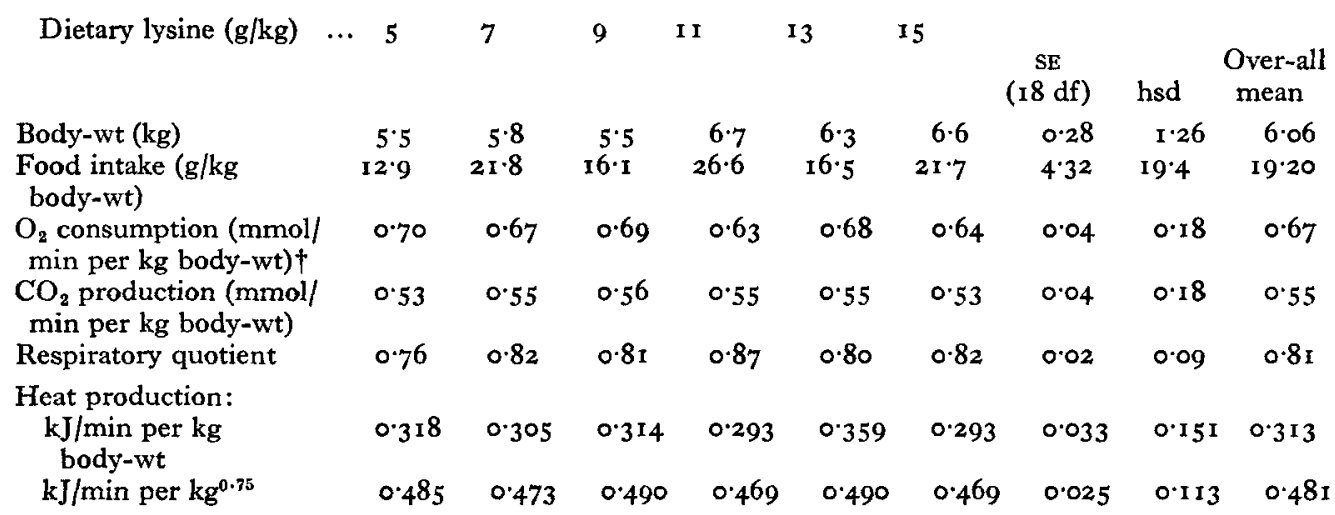

hsd, 'Honestly significant difference' of Tukey at $P>0.05$, as described by Steel \& Torrie (1960).

* For details of composition, see Table 1 .

+ Molar volume at standard temperature and pressure: $\mathrm{O}_{2} 22 \cdot 3921, \mathrm{CO}_{2} 22 \cdot 2631$.

Table 5. Summary of effect of dictary lysine level on plasma lysine concentration, and total and radioactive carbon dioxide produced by growing piglets given a semi-purified diet* containing $200 \mathrm{~g}$ crude protein (nitrogen $\times 6 \cdot 25) / \mathrm{kg}$, after infusion of $2 \mu \mathrm{Ci}$ $\mathrm{L}-\left[U-{ }^{14} C\right]$ lysine

Dietary lysine (g/kg) $\quad \ldots$

(Mean values for four piglets/treatment)

\begin{tabular}{|c|c|c|c|c|c|c|c|c|}
\hline$(\mathrm{g} / \mathrm{kg}) \quad \ldots$ & 5 & 7 & 9 & I I & 13 & 15 & $\begin{array}{c}\text { SE } \\
(18 \mathrm{df})\end{array}$ & hsd \\
\hline Body-wt (kg) & $5 \cdot 5$ & $5 \cdot 8$ & $5 \cdot 5$ & 6.7 & $6 \cdot 3$ & $6 \cdot 6$ & 0.2 & - \\
\hline $\begin{array}{l}\text { Food intake during } \\
\text { gas-exchange study }(\mathrm{g})\end{array}$ & 71 & 122 & 86 & I 77 & 105 & 146 & - & - \\
\hline $\begin{array}{l}\text { Plasma lysine con- } \\
\text { centration }(\mu \mathrm{mol} / \mathrm{l})\end{array}$ & 99 & 88 & 72 & 83 & 88 & 125 & I 8 & 79 \\
\hline $\begin{array}{l}\mathrm{CO}_{2} \text { produced during } \\
\text { gas-exchange study } \\
\text { (mol) }\end{array}$ & $1 \cdot 05$ & $I \cdot 14$ & I.09 & $I \cdot 32$ & $I \cdot 24$ & $I \cdot 25$ & 0.08 & 0.36 \\
\hline $\begin{array}{l}\text { Radioactivity recovered } \\
\text { as }{ }^{14} \mathrm{CO}_{2}: \text { disintegra- } \\
\text { tions } / \mathrm{min}\left(\times 10^{-4}\right)\end{array}$ & $14{ }^{*} \mathrm{I}$ & $\mathrm{r}_{4} \cdot 8$ & $16 \cdot 3$ & 13.2 & 10.8 & $16 \cdot 5$ & 0.97 & 4.4 \\
\hline$\%$ dose & $3 \cdot 20^{a b}$ & $3 \cdot 35^{a b}$ & $3 \cdot 68^{b}$ & $2 \cdot 99^{a b}$ & $2 \cdot 45^{a}$ & $3 \cdot 73^{b}$ & 0.22 & 0.97 \\
\hline
\end{tabular}

hsd, 'Honestly significant difference of, Tukey at $P>0.05$, as described by Steel \& Torrie (I960). Values with the same superscript were not significantly different: $P \leqslant 0.05$.

* For details of composition, see Table $\mathrm{r}$.

by the level of the lysine in the diet and the over-all mean value was $0.3^{1} 3 \mathrm{~kJ}(75 \mathrm{cal}) /$ min per kg body-weight.

Less than $4 \%$ of the activity from the tracer dose of $\left[{ }^{14} \mathrm{C}\right]$ lysine was recovered as ${ }^{14} \mathrm{CO}_{2}$ from the piglets which had received any of the diets containing the different lysine levels (Fig. 2), and there was no indication of reaching a plateau in activity. 


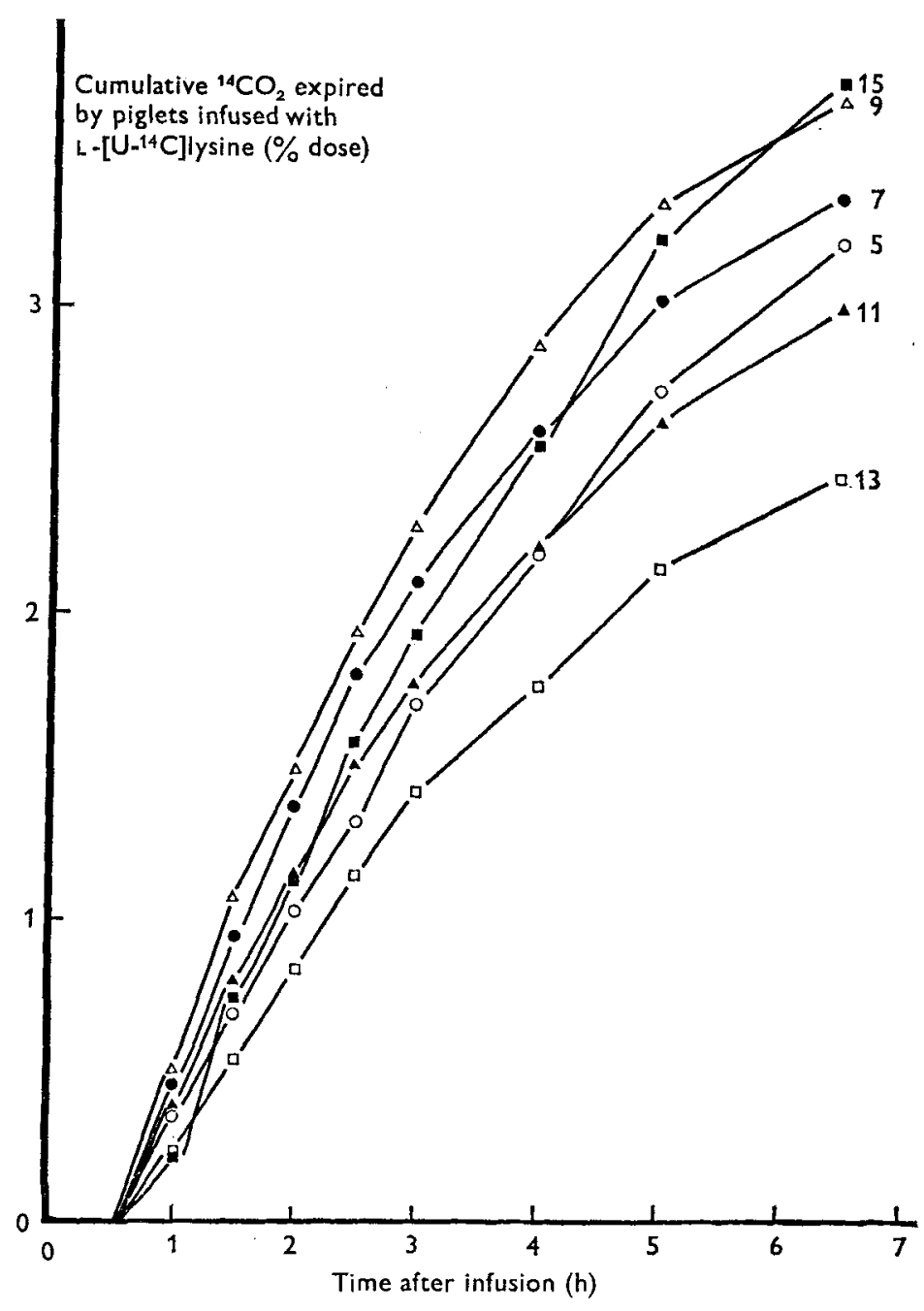

Fig. 2. Cumulative recoveries (\% dose) of ${ }^{14} \mathrm{C}$ as ${ }^{14} \mathrm{CO}_{2}$ in $6 \mathrm{~h}$ after the infusion of a dose of $2 \mu \mathrm{Ci} \mathrm{L}$-[U-14C]lysine to piglets of $5 \cdot 5-6 \cdot 7 \mathrm{~kg}$ live weight receiving diets containing graded levels of lysine $(\mathrm{g} / \mathrm{kg}):(O), 5 ;(\odot), 7 ;(\triangle), 9:(\Delta), 11 ;(\square), 13 ;(\square), 15 ;$ four piglets/diet. Pumps started to ventilate environmental chambers $30 \mathrm{~min}$ after infusion of dose. For details of diets, see Table 1 , and of experimental procedures see p. 371 .

There was no simple effect of level of lysine in the diet on recovery of the dose: the highest recovery was from the piglets which had received the diet containing the highest level of lysine $(15 \mathrm{~g} / \mathrm{kg})$, whilst the lowest recovery was from the piglets which had received the second highest level of dietary lysine $(13 \mathrm{~g} / \mathrm{kg})$.

The summary of the results obtained after the infusion of the $\left[{ }^{14} \mathrm{C}\right]$ lysine (Table 5) indicated that although the dietary lysine was increased from 5 to $15 \mathrm{~g} / \mathrm{kg}$, there were no significant increases in total $\mathrm{CO}_{2}$ production as a result of increasing the lysine level of the diet. However, there was a tendency for the recovery of ${ }^{14} \mathrm{CO}_{2}$ to increase as the level of dietary lysine increased from 5 to $9 \mathrm{~g} / \mathrm{kg}$, but as the dietary level of lysine increased from 9 to $13 \mathrm{~g} / \mathrm{kg}$ the recovery tended to decrease. However, the last 
increment in dietary lysine, from 13 to $15 \mathrm{~g} / \mathrm{kg}$, resulted in a marked increase in the recovery of the activity in the $\mathrm{CO}_{2}$. The difference between the recoveries from the diets containing 13 and $15 \mathrm{~g}$ lysine $/ \mathrm{kg}$ was statistically significant $(P \leqslant 0.05)$.

\section{DISCUSSION}

The Yorkshire piglets in this study responded to increasing the level of dietary lysine by increasing growth: Mitchell, Becker, Jensen, Norton \& Harmon (1965) found a similar response when they increased the level of lysine from $9^{\cdot}$ I to $15^{\cdot} \mathrm{I} \mathrm{g} / \mathrm{kg}$ in a semi-purified diet containing $220 \mathrm{~g}$ crude protein $/ \mathrm{kg}$, however, they concluded that their young pigs (2-8 weeks of age) required $12 \cdot 4 \mathrm{~g}$ lysine $/ \mathrm{kg}$. This estimate is higher than the value of $9.6 \mathrm{~g} / \mathrm{kg}$ recommended by the (US) National Research Council (1973).

The primary objective in measuring the concentrations of the free amino acids in the plasma in this study was to allow an estimation of the dilution of the dose of ${ }^{14} \mathrm{C}$-labelled lysine, and thus the samples were taken from piglets which had been adapted to the dietary regimen for at least $\mathrm{r} 4 \mathrm{~d}$ and which had been fasted overnight. Even with this pretreatment increasing the level of lysine in the diet from 13 to $15 \mathrm{~g} / \mathrm{kg}$ tended to increase the concentration of free lysine in the plasma. Braude, Fulford, Mitchell, Myres \& Porter (1974) have reported that the level of dietary lysine had its maximum effect on the concentration of lysine in the plasma of growing pigs $2 \mathrm{~h}$ after consumption of the meal. Mitchell, Becker, Jensen, Harmon \& Norton (r 968) took blood samples from ad lib.-fed pigs which were older than those used in the present study and found that the free lysine concentration in plasma increased from 118 to $400 \mu \mathrm{mol} / \mathrm{l}$ as the level of lysine in the diet increased from 6.8 to I I $8 \mathrm{~g} / \mathrm{kg}$. They also noted a tendency for the total concentration of the free amino acids in the plasma to decrease as the dietary level of lysine was reaching the requirement; the same trend was found in the present study. The significant decrease in the concentration of threonine in the plasma when the level of dietary lysine was increased from I I to $13 \mathrm{~g} / \mathrm{kg}$ supported the conclusion that it was the second limiting amino acid in the experimental diet. Stockland, Meade \& Melliere (1970) found a similar effect of dietary lysine level on the concentrations of lysine and threonine in the plasma of rats, and Kroening, Pond \& Loosli (1965) found that the growth response of piglets was limited by the threonine content of their basal diet.

In these experiments no influence of dietary balance, with respect to lysine on the heat production was found, extending the findings of Walker (1974) with lambs, and Trela (1973) with chickens, to the piglet. In these studies the 5-9 kg piglets were releasing $0.313 \mathrm{~kJ} / \mathrm{min}$ per $\mathrm{kg}$ body-weight. This value compares well with those of 0.279 and $0.347 \mathrm{~kJ} / \mathrm{min}$ per $\mathrm{kg}$ body-weight from two experiments with 5 -d-old suckled piglets, and is approximately twice the values for $24 \mathrm{~h}$-fasted, 5 -d-old piglets $(0.133$ and $0.181 \mathrm{~kJ} / \mathrm{min}$ per $\mathrm{kg}$ body-weight) found in a previous study (Bayley \& McDonald, I970). Jordan \& Brown (1970) found values of $0.175 \mathrm{~kJ} / \mathrm{min}$ per $\mathrm{kg}$ bodyweight for $36 \mathrm{~h}$-fasted, 3 -week-old piglets.

Nielsen (1970) worked with pigs of $24 \mathrm{~kg}$ body-weight and found heat outputs of 


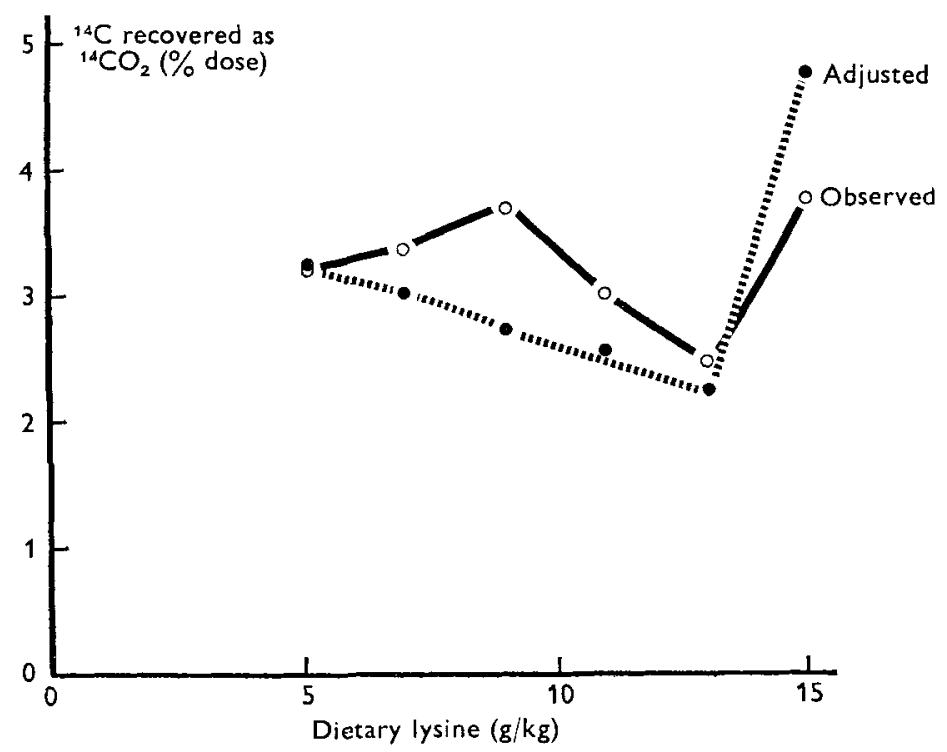

Fig. 3. Determined $(\mathrm{O}-\mathrm{O})$ and adjusted $\cdots)$ recoveries $\left(\%\right.$ dose) of ${ }^{14} \mathrm{C}$ as ${ }^{14} \mathrm{CO}_{2}$ in $6 \mathrm{~h}$ after the infusion of a dose of $\mathrm{L}-\left[\mathrm{U}^{-14} \mathrm{C}\right]$ lysine to piglets of $5 \cdot 5-6.7 \mathrm{~kg}$ live weight receiving diets containing graded levels of dietary lysine. Adjusted values were calculated on the basis of equal dilution of the tracer dose in the blood plasma using the concentration of free lysine in the plasma of the piglets receiving the diet containing $5 \mathrm{~g}$ lysine $/ \mathrm{kg}$. For details of diets see Table 1 , and of experimental procedures, see p. 371 .

$0.254 \mathrm{~kJ} / \mathrm{min}$ per $\mathrm{kg}$ body-weight which was similar to the values of 0.245 reported by Gray \& McCracken (1974) for $22 \mathrm{~kg}$ pigs. Thorbek (1975) found that the heat output of $24 \mathrm{~kg}$ pigs was $0.268 \mathrm{~kJ} / \mathrm{min}$ per $\mathrm{kg}$ body-weight. Expressing these values for heat output on a metabolic body size (body-weight ${ }^{0.75}$ ) basis gives $0.555,0.529$ and $0.601 \mathrm{~kJ} / \mathrm{min}$ per $\mathrm{kg}$ body-weight ${ }^{0.75}$ for values given by Nielson (1970), Gray \& McCracken (1974) and Thorbek (1975) respectively, which are higher than the value of $0.48 \mathrm{I}$ found in the present experiment, presumably because of the low food intake of the pigs in the present study whilst they were in the chambers.

The determined recoveries of the label as ${ }^{14} \mathrm{CO}_{2}$ from the tracer dose of lysine (Fig. 3) indicated the complex relationship with dietary lysine level. However, adjusting these recoveries for the lysine concentration in the plasma as described by Chavez \& Bayley (1976), gave a considerably simpler relationship: for the first four increments of dietary lysine there was a linear decrease in the amount of ${ }^{14} \mathrm{C}$ recovered in $\mathrm{CO}_{2}$, with a marked increase for the highest level of dietary lysine. These adjusted values supported the conclusion that the Yorkshire piglets in this study had a requirement for lysine of between 13 and $15 \mathrm{~g} / \mathrm{kg}$ diet. The 6-7-week-old suckled piglet has a lysine intake of approximately $4 \mathrm{~g} / \mathrm{d}$ (Jones, 1969 ) from the sow's milk which contains $64 \mathrm{~g}$ crude protein with a lysine content of $72.5 \mathrm{~g} / \mathrm{kg}$ protein (Bowland, 1966). The requirement of $14 \mathrm{~g}$ lysine $/ \mathrm{kg}$ diet reported here is equivalent to an intake of $3.9 \mathrm{~g}$ lysine/d, with the pigs consuming $0.278 \mathrm{~kg}$ diet.

Thus the requirement for lysine estimated by this method agrees closely with the requirement estimated from the determination of growth rate and plasma concentra- 
tion, providing some empirical justification for the procedure. Neale \& Waterlow (1974) criticized the study of amino acid oxidation as a means of estimating dietary requirements because of the difficulties of defining the metabolic pool into which the dose was diluted. However, the lysine requirement estimated by Brookes et al. (1972) for the rat agreed well with their estimates based upon other procedures.

Estimates of dietary requirements for the young pig are usually made by using growth rate as a response measurement, and in most instances growth rates on experimental diets are lower than when the piglets receive sow's milk. In the present studies the metabolism of lysine has been studied in an attempt to assess the dietary level which minimizes the catabolism of a tracer dose of the amino acid. The level which achieves this may not be the level which results in maximum growth, and although there are no other direct studies of amino acid metabolism in the young pig, Cooke, Lodge \& Lewis (1972) using pigs growing from 23 to $59 \mathrm{~kg}$ found maximum growth rate on a diet containing $174 \mathrm{~g}$ crude protein, $10.5 \mathrm{~g}$ lysine and $8 . \mathrm{I} \mathrm{g}$ methionine plus cystine/kg; higher crude protein levels reduced growth rate. However, they found a linear increase in the dissectable lean content of the carcasses up to the highest level of dietary crude protein used in the experiment. This diet contained $275 \mathrm{~g}$ crude protein, $15.9 \mathrm{~g}$ lysine, and $12.4 \mathrm{~g}$ methionine plus cystine/kg diet. Since lean deposition is more closely associated with protein synthesis than is the total increase in weight of the pig, these findings are in agreement with the results of the present experiment, that the levels of amino acid needed to maximize growth rates are not necessarily equal to those which result in marked increases in amino acid catabolism.

Although the effects of compensatory growth (Duckworth, 1965) may mean that imprecision in balancing the nutrient levels in the diet on the over-all development of the pig may be of little practical consequence, the theoretical basis of the system used to define the piglets' dietary requirements should be amenable to precise description.

This work was supported by the National Research Council of Canada and the Ontario Ministry of Agriculture and Food. The authors are grateful to D. W. Fitzpatrick for his assistance.

\section{REFERENCES}

Agricultural Research Council (1967). The Nutrient Requirements of Farm Livestock No. 3. Pigs. London: Agricultural Research Council.

Association of Official Agricultural Chemists (1970). Official Methods of Analysis, I Ith ed. Washington, DC: Association of Official Agricultural Chemists.

Bayley, H. S. \& McDonald, M. S. (1970). In Energy Metabolism of Farm Animals, p. ${ }_{57}$ [A. Schurch and C. Wenk, editors]. Zurich: Juris Druck.

Bowland, J. P. (1966). Swine in Biomedical Research, p. 97 [L. K. Bustad and R. O. McClellan, editors]. Richland, Washington: Battelle Memorial Institute.

Braude, R., Fulford, R. J., Mitchell, K. G., Myres, A. W. \& Porter, J. W. G. (I974). Livestock Prad. Sci. I, 383 .

Brookes, I. M., Owens, F. N. \& Garrigus, U. S. (1972). Y. Nutr. 102, 27.

Brown, J. A. \& Cline, T. R. (1974). F. Nutr. 104, 542.

Chavez, E. R. \& Bayley, H. S. (1976). Br. F. Nutr. 36, I89.

Cooke, R., Lodge, G. A. \& Lewis, D. (1972). Anim. Prod. 14, 35.

Duckworth, J. E. (I965). Anim. Prod. 7, 165.

Gallo, J. T. \& Pond, W. G. (1968). F. Anim. Sci. 27, 73. 
Gallo, J. T., Pond, W. G. \& Logomarsino, J. V. (1968). J. Anim. Sci. 27, rooo.

Gray, R. \& McCracken, K. J. (1974). In Energy Metabolism of Farm Animals, p. I61 [K. H. Menke, J. H. Lantzsch and J. R. Reichl, editors]. Hohenheim: University of Hohenheim Press.

Jones, A. S. (1969). In Nutrition of Animals of Agricultural Importance, part 2, p. 96 I [D. Cuthbertson, editor]. Oxford: Pergamon Press.

Jordan, J. W. \& Brown, W. O. (1970). In Energy Metabolism of Farm Animals, p. 16I [A. Schurch and C. Wenk, editors]. Zurich: Juris Druck.

Keith, M. O., Christensen, D. A. \& Owen, D. G. (1972). Can. F. Anim. Sci. 52, 163.

Kleiber, M. (196r). The Fire of Life. New York: John Wiley.

Knipfel, J. E., Keith, M. O., Christensen, D. A. \& Owen, B. D. (1972). Can. Y. Anim. Sci. 52, 143.

Kroening, G. H., Pond, W. G. \& Loosli, J. K. (1965). F. Anim. Sci. 24, 5 I9.

Mitchell, J. R. Jr, Becker, D. E., Jensen, A. H., Harmon, B. G. \& Norton, H. W. (1968). F. Anim. Sci. 27, 1327.

Mitchell, J, R. Jr, Becker, D. E., Jensen, A. J., Norton, H. W. \& Harmon, B. G. (1965). F. Anim. Sci. 24, 409 .

National Research Council (1973). Nutrient Requirements of Domestic Animals No. 2, Pigs, Washington, DC: National Academy of Sciences.

Neale, R. J. \& Waterlow, J. C. (1974). Br. Y. Nutr. 32, I I.

Newport, M. J., Chavez, E. R., Horney, F. D. \& Bayley, H. S. (1976). Br. F. Nutr. 36, 87 .

Nielsen, A. J. (1970). Beretn. Forsagslab. no. $3^{8 \mathrm{I}}$.

Oestemer, G. A., Hanson, L. E. \& Meade, R. J. (1973). F. Anim. Sci. 36, 679.

Steel, R. G. D. \& Torrie, J. H. (1960). Principles and Procedures of Statistics. New York: McGraw-Hill Book Co. Inc.

Stockland, W. L., Meade, R. J. \& Melliere, A. L. (1970). F. Nutr. 100, 925.

Thorbek, G. (1975). Beretn. St husdyrbr. Forsog. no. 424.

Trela, S. (1973). Nutr. Abstr. Rev. 45, 361.

Walker, D. M. (1974). In Energy Metabolism of Farm Animals, p. 75 [K. H. Menke, J. H. Lantzsch and J. Reichl, editors]. Hohenheim: University of Hohenheim Press.

Zimmerman, D. R. (1975). F. Anim. Sci. 40, 875.

Zimmerman, R. A. \& Scott, H. M. (1965). F. Nutr. 87, r3. 